\section{Efficacy of Heat-based Treatments in Eliminating the Recovery of the Sudden Oak Death Pathogen (Phytophthora ramorum) from Infected California Bay Laurel Leaves}

\author{
Tamar Y. Harnik, Monica Mejia-Chang, James Lewis, ${ }^{2}$ and \\ Matteo Garbelotto ${ }^{1}$ \\ Department of Environmental Sciences Policy and Management, University \\ of California, Berkeley, 151 Hilgard Hall, Berkeley, CA 94720
}

Additional index words. vacuum dehydration, spices, Umbellularia californica, sanitation, viability

\begin{abstract}
Phytophthora ramorum (Oomycota) (Werres et al., 2001) is the plant pathogen responsible for the lethal disease of several oak species in California known as sudden oak death. The pathogen also causes a foliar disease on Umbellularia californica (bay laurel or simply bay). Bay leaves have been identified as the major source of natural inoculum in California coastal woodlands. Because of the epidemiological relevance of bay leaves, their movement needs to be regulated. Our study shows that $P$. ramorum is highly heat tolerant and can be reisolated from artificially inoculated bay laurel leaves placed at $55{ }^{\circ} \mathrm{C}$ for up to 1 week. The pathogen cannot be recovered after 2 weeks at 55 ${ }^{\circ} \mathrm{C}$. Prolonged heat treatments, however, are impractical for bay leaves intended to be sold commercially as a spice, since they negatively impact the quality of the leaves. Here we describe a treatment involving a progressive and gradual heating process combined with the application of moderate vacuum. This method can be completed in 22 hours and is shown here to eliminate the recovery of $P$. ramorum without having a negative impact on the quality of the bay leaves.
\end{abstract}

The worldwide trade of agricultural crops and ornamental plants represents an increasing threat to natural ecosystems. Traded plants or even plant parts represent an ideal medium for the long-distance transport of pathogens, potentially resulting in the introduction of exotic microbes in new environments, where their aggressiveness on native plants may be extremely high due to the lack of coevolution (Wingfield et al., 2001).

The Oomycete Phytophthora ramorum (Werres et al., 2001) is a major pathogen of native plant communities in California and southern Oregon, and causes the disease commonly referred to as sudden oak death (SOD). This pathogen was recently identified as the primary agent causing SOD (Garbelotto et al., 2001; Rizzo et al., 2002). The same organism was also recently described as a pathogen of rhododendron and viburnum in European nurseries (Werres et al., 2001). The origins of this pathogen are still unknown. The low genetic

Received for publication 23 Dec. 2003 . Accepted for publication 15 Mar. 2004. The critical comments on the manuscript by D. Rizzo and W. Schweigkofler were much appreciated. We also thank G. S. Biging for advice on the statistical analysis. This work is dedicated to the memory of Jamie Westoby. Part of this study was funded by the USDA award 02-JV11272138-066 granted through the Pacific Southwest Forest/Range Experiment station.

1'E-mailmatteo@nature.berkeley.edu.

${ }^{2}$ Bayseng Spice Company, 21 Old Tunnel Road, Orinda, CA 94563. diversity identified in the U.S. population by amplified fragment-length polymorphism (AFLP) analyses (Garbelotto et al., 2003a), and the limited geographic distribution of the pathogen, which is significantly smaller than the natural range of distribution of its plant hosts, suggest it may be an introduced organism (Rizzo and Garbelotto, 2003). The host range of $P$. ramorum is extremely broad and includes species native not only to California, but to many world regions (Davidson et al., 2003). The high tree mortality caused by $P$. ramorum in coastal California, combined with the limited knowledge on this pathogen's biology and epidemiology, have prompted regulatory agencies from the European Union, South Korea, Canada and the U.S. to implement quarantines against the movement of plant material or soil that may be at risk of harboring the pathogen (Garbelotto et al., 2003a; USDA, 2002)

Umbellularia californica (Lauraceae) (bay laurel, bay, oregon myrtle, pepperwood tree) is a widespread and abundant tree native to California and southern Oregon. This species is the most common host for $P$. ramorum in California (Rizzo and Garbelotto, 2003). The symptoms caused by $P$. ramorum on bay laurel are limited to a foliar blight (i.e., dead spots or dark blotches on the leaves), and there have been no reports of death of infected trees (Davidson et al., 2002; Garbelotto et al., 2002). Nevertheless, infected bay leaves play a key epidemiological role in the spread of SOD (Davidson et al., 2002). Two studies have shown a significant relationship between the presence of bay laurel and the presence of SOD on neighboring oak trees (Kelly and Meentemeyer, 2002; Swiecki and Bernhardt, 2002).

Sporulation of $P$. ramorum on bay leaves is extraordinarily prolific. Even after several weeks dry leaves may support sporulation if rehydrated (Rizzo and Garbelotto, 2003) Sporangia and chlamydospores are produced by $P$. ramorum either on the surface of bay leaves or embedded within the leaf's mesophyll (Jennifer Parke, personal communication). P. ramorum sporangia are microscopic ovoid structures that can be airborne (rain splash, wind-driven rain). Upon landing on wet surfaces, mature sporangia may germinate and directly infect plant tissue or release a swarm of motile zoospores which will infect plant tissue (Davidson et al., 2002). The role played by the round-shaped thick-walled microscopic chlamydospores is still unclear, but they are thought to serve as resting propagules, allowing the pathogen to survive during climatically unfavorable spells similar to other Phytophthora spp. (Erwin and Ribeiro, 1996).

The leaves of bay laurel are used for culinary purposes as a spice. Dried plant material is distributed locally or exported nationally and internationally. Since leaf collecting occurs in California and southern Oregon, infected leaves could potentially be placed on the market. An excess of $5000 \mathrm{t}$ of california bay laurel leaves, worth several million dollars, is placed on the market yearly (James Lewis, personal communication). Because of the difficulty in diagnosing early symptoms, visual screening of processed leaves will not prevent trading of infected, but apparently healthy, leaves. An alternative approach to the visual screening of plant materials involves the generalized application of a treatment that is capable of eliminating the recovery of $P$. ramorum from infected leaves.

Leaves used as spices are normally preserved through drying. The drying process is critical not only to prevent molding, but also to inhibit chemical reactions that would otherwise reduce the shelf life of the product (King et al., 2000, Madamaba and Liboon, 2001). The purpose of this paper is to test whether a treatment already in use by a commercial provider of bay leaves (here defined as Treatment 3) may be considered as a viable sanitation tool for infected bay leaves. Three additional treatments were also tested and are discussed in this article.

\section{Materials and Methods}

Heat treatments. Asymptomatic bay leaves were collected from 10 different trees on the campus of the University of California at Berkeley so as to account for differences in individual tree susceptibility. Leaves were inoculated in the lab using an agar slurry previously infected with the pathogen strains Pr 1 (coast live oak, Marin county), Pr 2 (Tanoak, Marin county) and Pr 5 (Tanoak, Marin county). Leaves were scratched with a needle before being inoculated to favor infection by 
P. ramorum. Leaves were then layered with moist paper towels inside a sealed container to ensure relative humidity values above $90 \%$. Lesions began to develop within a few days and the leaves were clearly symptomatic and ready for the heat treatment $10 \mathrm{~d}$ after the inoculation date.

Pathogen recovery was determined by plating symptomatic tissue from leaf lesions directly on a modified selective medium for Phytophthora spp.: pimaricin-ampicillin-rifampicin-PCNB ( $\mathrm{P}_{10} \mathrm{ARP}$ ) (Erwin and Ribeiro, 1996) that used one-fourth the amount of PCNB as compared to the original recipe.

For the heat treatments, ten bay leaves were incubated at $55{ }^{\circ} \mathrm{C}$ for each of two treatment times: 1 week (Treatment 1) and 2 weeks (Treatment 2). Isolations were also attempted from sets of 10 untreated leaves, stored at room temperature (about $20^{\circ} \mathrm{C}$ and sampled at the beginning of the experiment (pretreatment) and after 2 weeks (positive control). Treatments 1 and 2 and the controls were initiated at the same time. At the end of each trial, treatment and control leaves were incubated in a moist chamber for $48 \mathrm{~h}$ at room temperature to induce sporulation and thus enhance the success of recovery of the pathogen. Each experiment in its entirety was replicated once.

Vacuum +heat treatments. Two vacuum treatments, both aimed at drying bay leaves for commercial culinary purposes, were tested at a commercial facility (Bayseng spice company, Orinda, Calif.). The treatments were performed on artificially inoculated leaves three times. An additional experiment was performed once on naturally infected leaves collected in China Camp State Park (Marin County, Calif.). Experimental approach and design, sample size, and positive controls for Treatment 1 and 2 of naturally infected leaves were identical to those described for artificially inoculated leaves.

Bay leaves were artificially infected as described above, using isolates Pr1 and Pr52 (rhododendron, Marin County). Ten infected leaves were placed in each of three mason jars, for a total of thirty leaves, and the mouth of each jar was then sealed with filter paper No. 1 (11 $\mu \mathrm{m})$, (Whatmann, Kent, United Kingdom). The use of filter paper prevented the contamination of the drying equipment by $P$. ramorum, while allowing for a vacuum to be created inside the jar.

In Treatment 3, the jars were placed on shelves in a vacuum chamber, and were treated following a standard protocol used by the facility, in which the vacuum pressure was recorded (Fig. 1), and gradually reached 0.133 $\mathrm{kPa}$. Temperature in the drying chamber was gradually increased from 15 to $60{ }^{\circ} \mathrm{C}$ during the course of $5 \mathrm{~h}$ and then gradually lowered to $15^{\circ} \mathrm{C}$ (Fig. 1). Leaves were left inside the chamber for a total time of $22 \mathrm{~h}$. In Treatment 4 , jars were maintained at $15^{\circ} \mathrm{C}$ and vacuum $(0.133 \mathrm{kPa})$ was applied for $1 \mathrm{~h}$.

At the same time Treatments 3 and 4 were being tested, three jars, each containing ten infected bay laurel leaves, were left at room temperature as a control treatment. The control leaves and the leaves used in Treatments 3 and 4 were collected from the same batch of artificially inoculated leaves.

At the end of each treatment, all leaves were brought to the lab and processed immediately. For Treatment 3, Treatment 4, and the control, five leaves were randomly sampled, from each jar, for a total of 15 leaves, and 5 segments per leaf were directly plated onto selective medium (modified $\mathrm{P}_{10} \mathrm{ARP}$ ). Segments were taken from the borders of the infected area, where a black zone line is formed between the healthy and diseased tissue. In the case of the naturally infected leaves one segment from each leaf was plated, using 10 leaves total from each treatment. The control leaves were plated at

A.

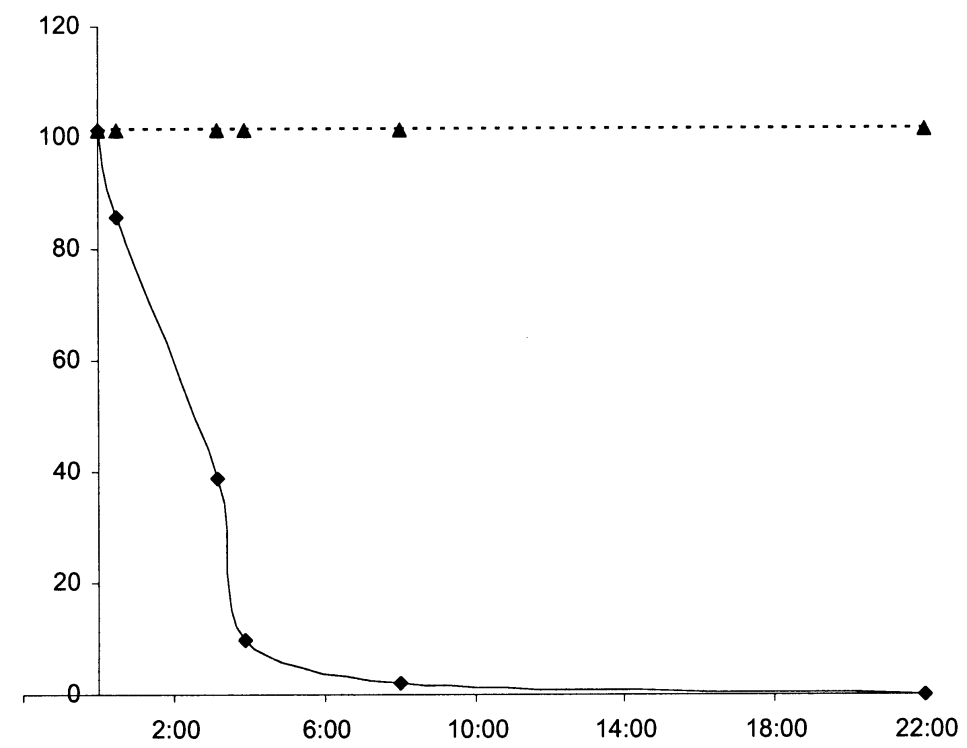

B.

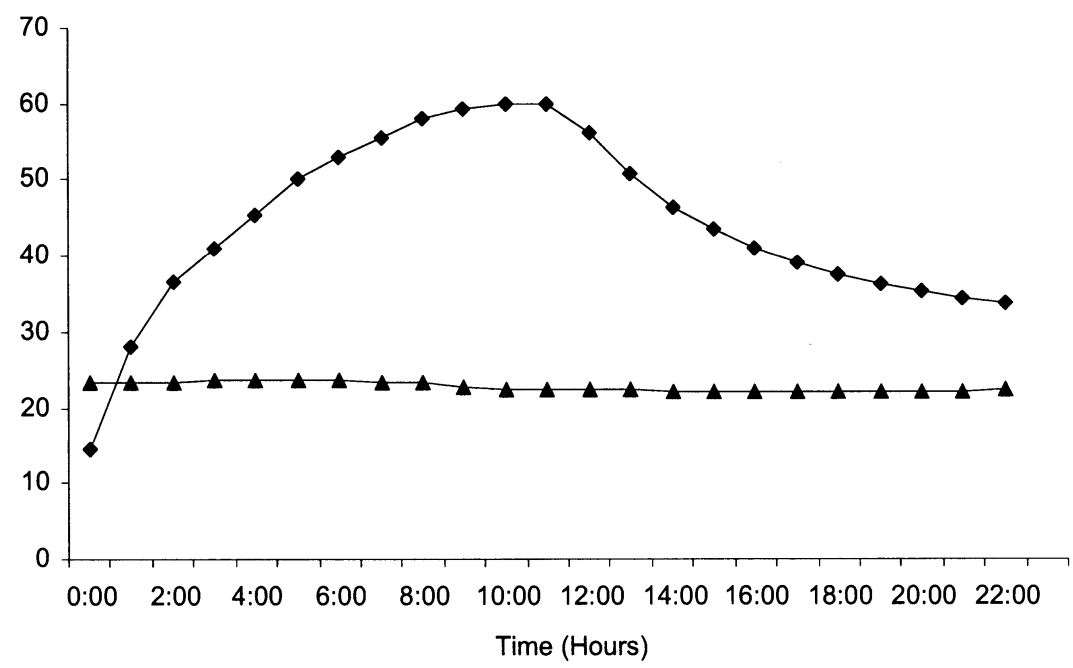

Fig. 1. Pressure $(\mathbf{A})$ and temperature $\left( \pm 3{ }^{\circ} \mathrm{C}\right)(\mathbf{B})$, conditions as a function of time for Treatment 3 in the test chamber (diamonds) and for the untreated controls (triangles). 
ratio (LR) test was used two compare the two heat treatments and the two heat+vacuum treatments with the respective controls. Pairwise comparisons between each treatment and the respective controls were performed using the two-tail value of Fisher's exact test. A LR test was used to compare results from the three replicate heat+ vacuum trials. Its result $(\mathrm{n}=$ $135, \mathrm{DF}=2, \mathrm{LR}$ chi square $=0.411, P=0.814$ ) indicated there were no differences among the three trials. Results were thus analyzed once for the entire pooled dataset. Each leaf was considered as an independent experimental unit, a likely assumption considering the temperature and humidity during the tested treatments would be absolutely unfavorable to cross-contagion.

A leaf was considered positive (1) for $P$. ramorum if it yielded at least one positive isolation out of five, it was considered negative (0) if all five isolations failed to produce a colony of the pathogen. All analyses were done using the JMPv.5 statistical analysis software (Release 5.0.1, 2002, SAS Institute Inc. Cary, N.C.). Analyses for the artificially infected leaves (three replicate trials) and for naturally infected leaves (one trial) were conducted separately.

\section{Results}

Heat treatments. There were significant differences when comparing the two heat treatments and the control $(\mathrm{n}=30, \mathrm{DF}=2, \mathrm{LR}$ chi square $=27.9, P<0.0001)$. However treatments were not equally effective. The recovery of $P$. ramorum from inoculated bay leaves was reduced without strong statistical significance (n $=20$, two-tail Fisher's exact test $P=0.08$ ) but not completely eliminated by exposure at $55{ }^{\circ} \mathrm{C}$ for 1 week (Treatment 1 , Table 1 ). On the other hand, a 2-week exposure at $55^{\circ} \mathrm{C}$ (Treatment 2, Table 1) completely eliminated the recovery of $P$. ramorum, while untreated controls were still viable $((\mathrm{n}=20$, two-tail Fisher's exact test $P<0.0001$ ). Identical results were obtained in the replicated experiment, but are not presented due to the misplacement of the leaves used for positive control. It should be noted, however that infectivity of bay leaves is known to persist for several weeks (Rizzo and Garbelotto, 2003).

Vacuum +heat treatments. Significant differences in recovery of $P$. ramorum were found among the two heat+vacuum treatments and the controls $(\mathrm{n}=135, \mathrm{DF}=2$, LR chi square $=81.08, P<0.0001)$, however the efficacy of the two treatments was not comparable. $P$. ramorum could still be isolated from bay leaves after the 1-h treatment (Treatment 4, Table 2). Furthermore, the treatment did not significantly reduce the recovery of the pathogen $(n=90$, two-tail Fisher's exact test $P=0.087$ ). On the other hand, after the 22-h treatment (Treatment 3 , Table 2), the pathogen recovery was reduced to zero, a significant change from the recovery retained by untreated controls $(\mathrm{n}=90$, two-tail Fisher's exact test $P<0.0001)$.

Treatment 3 was equally effective on leaves naturally infected by $P$. ramorum, and resulted in no post-treatment pathogen recovery $(n=60$, two-tail Fisher's exact test $P<0.0001$ ).

\section{Discussion}

The preservation of plant parts to be sold as spice is often achieved by dehydration obtained by direct exposure to heat. The temperature used for this process will determine the drying rate to which plant parts are subjected (Madamaba and Liboon, 2001). Dehydration that is too rapid can damage the plant tissue and negatively affect the organolectic properties of the spice. By operating in a vacuum, temperatures don't need be as high to dry the plant substrate, thus better preserving the quality of the product. (Madamaba and Liboon, 2001).

Heat is also a common tool used to sanitize plant material from pests and pathogens (Katan et al., 1976). Processes involving heat can thus theoretically be used to dry the plant material and to sanitize it from pathogens at the same time. The varying ability of pathogens to withstand heat may affect their suitability for sanitation by heat treatments. Heat tolerance is known to vary not only between, but also within species (Juarez-Palacios et al., 1991; Mizubuti and Fry, 1998; Mizubuti et al., 2000). Different types of infectious propagules (e.g., sporangia, zoospores, and chlamydospores) may also display different sensitivity to heat, although produced by the same organism.

Several studies have shown a dramatic decline in the recovery of different Phytophthora spp. when exposed to high temperatures (Katan et al., 1976; Zentmyer et al, 1976). Chlamydospores of $P$. cinnamomi were not recovered from infested soil after exposure to $45^{\circ} \mathrm{C}$ for $20 \mathrm{~min}$. Oospores (i.e., the dormant spore produced by the sexual mating of two isolates) of P. megasperma survived a 30-minute exposure to $45^{\circ} \mathrm{C}$, but oospores of $P$. cactorum did not germinate after the treatment (Juarez-Palacios et al., 1991). Chlamydospores of $P$. nicotianae failed to germinate after exposure to $53{ }^{\circ} \mathrm{C}$ for only $3 \mathrm{~min}$ (Coelho et al., 2000). Although $P$. ramorum has been shown to be a pathogen favored by cool temperatures, with an optimum around $18{ }^{\circ} \mathrm{C}$ (Werres et al., 2001), we have shown here that $P$ ramorum in plant tissue may be fairly resilient to heat treatments.

Because of the potential for movement of this pathogen into new areas, the only acceptable treatment is one that will completely eliminate recovery of the pathogens. A 2-week

Table 1 . Effect of heat treatments $\left(55^{\circ} \mathrm{C}\right)$ on the recovery of Phytophthora ramorum from artificially inoculated bay leaves.

\begin{tabular}{lccc}
\hline Treatment & $\begin{array}{c}\text { No. of } \\
\text { leaves }\end{array}$ & $\begin{array}{c}\text { Recovery rate }(\%) \\
\text { after treatment }\end{array}$ & $\begin{array}{c}\text { P from Fisher's exact test } \\
\text { (two-tail) compared to control }\end{array}$ \\
\hline $1(1$ week $)$ & 10 & 60 & 0.08 \\
$2(2$ weeks $)$ & 10 & 0 & $<0.0001$ \\
Control (no treatment) & 10 & 100 & \\
\hline
\end{tabular}

Table 2. Effect of vacuum+heat treatments on the recovery of Phytophthora ramorum from artificially inoculated bay leaves. Data shown is pooled from three replicate trials.

\begin{tabular}{lccc}
\hline Treatment & $\begin{array}{c}\text { No. of } \\
\text { leaves }\end{array}$ & $\begin{array}{c}\text { Recovery rate }(\%) \\
\text { after treatment }\end{array}$ & $\begin{array}{c}\text { P from Fisher's exact test } \\
\text { (two-tail) compared to control }\end{array}$ \\
\hline $3(22 \mathrm{~h})$ & 45 & 0 & $<0.0001$ \\
$4(1 \mathrm{~h})$ & 45 & 75.5 & $<0.087$ \\
Control (no treatment) & 45 & 89 & \\
\hline
\end{tabular}

exposure at $55^{\circ} \mathrm{Cachieved} \mathrm{this} \mathrm{goal.} \mathrm{Although}$ it is likely that the recovery may decline to 0 in between the 1-week and the 2-week timeline, a 2-week treatment appears to be a prudent sanitation timeline. It should also be noted that, based on the type of inoculum and the nature of infection, it may be possible to eliminate $P$. ramorum recovery with as little as a $24-\mathrm{h}$ exposure to $55^{\circ} \mathrm{C}$. Because it may be difficult to determine the resilience of the pathogen in infected plant substrate, the most conservative (e.g., long) treatments should always be selected. Accepted sanitation methods for this and other Phytophthora species, including solarization and composting, rely approximately on a 2-week exposure to heat (Garbelotto, 2003b; Juarez- Palacios et al., 1991).

In the case of leaves that are to be commercialized as a spice, exposure to $55^{\circ} \mathrm{C}$ for several days is not an acceptable approach, because the essential volatiles are lost and the leaves become extremely dry and unsuitable for cooking. Shorter treatments, possibly involving lower temperatures, are thus needed to dry the leaves for commercial purposes and eliminate potential infections by $P$. ramorum at the same time.

A quick treatment (Treatment 4) involving exposure of the leaves to a moderate level of vacuum $(0.133 \mathrm{kPa})$ for only $1 \mathrm{~h}$ was ineffective, but a 22-h treatment (Treatment 3) involving a combination of heat and vacuum leaves of good quality from which $P$. ramothe heat is gradually increased and decreased over the course of the treatment, resulting in a 1- or 2-h exposure to temperatures over 50 ${ }^{\circ} \mathrm{C}$, thus preserving the essential volatiles that are sought after when cooking.

The process here described and tested as Treatment 3 was developed and is being currently used by a commercial producer in California to provide high quality bay leaves. We have shown here that by this treatment, such leaves are not immediately infective even if highly infected with the SOD pathogen. Howpe noted that lack of recovery climatic conditions may trigger dormancy periods in spores of Phytophthora followed by a reestablishment of viability when conditions was extremely successful in providing bay the pathogen is dead. In nature, unfavorable 
are once again favorable (Erwin and Ribeiro, 1996). Although medium- and long-term studies are needed to address this issue for $P$. ramorum subject to heat and vacuum+heat treatments, we have found no report of any Phytophthora species surviving prolonged heat treatments. Considering the relatively low risk posed by cooking spices as a means of pathogen introduction, we believe that the elimination of visibly infected leaves, and the treatment of leaves as described for Treatment 3 , eliminate any risk of contagion due to bay leaves commercialized as cooking spice.

\section{Literature Cited}

Coelho L., D.J. Mitchell, and O. Chellemi. 2000. Thermal inactivation of Phytophthora nicotianae. Phytopathology 90:1089-1097.

Davidson, J.M., D.M. Rizzo, and M.Garbelotto 2002. Phytophthora ramorum and Sudden Oak Death in California: II. Pathogen transmission and survival. In: R. Stanford, D. McCreary, and K.B. Purcell (eds.). Proc 5th Oak Symp.: Oak in California's Changing Landscape. San Diego, Calif. USDA Forest Service, Gen. Tech. PSWGTR-184. p. 741-749.

Davidson, J.M., S. Werres, M. Garbelotto, E.M. Handsen, and D.M. Rizzo. 2003. Sudden oak death and associated diseases caused by Phytophthora ramorum. Online. Plant Health Progress doi: 10, 10, 1094/PHP-2003-0707-01-DG.

Edwin D.C. and O.K. Ribeiro. 1996. Phytophthora diseases worldwide. APS Press, American Phytopathol. Soc., St. Paul, Minn.

Garbelotto, M., 2003b. Composting as a control for sudden oak death disease. BioCycle 44:53-56.

Garbelotto, M., J.M. Davidson, K. Ivors, P.E. Ma- loney, D. Hüberli, S.T. Koike, and D. Rizzo. 2003a. Non-oak native plants are main hosts for sudden oak death pathogen in California. Calif. Agr. 57(1): 18-23

Garbelotto, M. D.M. Rizzo, J.M. Davidson, and S.J. Frankel. 2002. How to recognize symptoms of diseases caused by Phytophthora ramorum causal agent of sudden oak death. USDA For. Serv. Pacific S.W. Reg. Publ.

Garbelotto, M., P. Svira, and D.M. Rizzo. 2001. Sudden oak death syndrome fell 3 oak species. Calif. Agr. 55(1):9-19

Juarez-Palacios C., R. Felix-Gastelum, R.J. Wakeman, E.J. Paplomatas, and J.E. DeVay. 1991. Thermal sensitivity of three species of Phytophthora and the effect of soil solarization on their survival. Plant Dis. 75:1160-1163.

Katan, J., A. Greenberger, H. Alon, and A. Grinstein. 1976. Solar Heating by polyethylene mulching for the control of diseases caused by soil-borne pathogens. Phytopathology 66:683-688.

Kelly, N.M. and R. Meentemeyer. 2002. Landscape dynamics of spread of Sudden Oak Death. Photo Eng. Rem. Sens. 68:1001-1009.

King, V.A., C.F.Liu, and Y.J. Liu. 2001. Chlorophyll stability in spinach dehydrated by freeze-drying and controlled low temperature vacuum dehydration. Food Res. Intl. 34:167-175.

Madamaba P.S. and F.A Liboon. 2001. Optimization of the vacuum dehydration of celery (Apium graveolens) using the response surface methodology. Drying Technol. 19(3,4):611-626.

Mizubuti, E.S.G., D.E. Aylor, and W.E. Fry. 2000 Survival of Phytophthora infestans sporangia exposed to solar radiation. Phytopathology 90:78-84.

Mizubuti, E.S.G. and W.E. Fry.1998. Temperature effect on developmental stages of isolates from three clonal lineages of Phytophthora infestans.
Phytopathology 88(8):837-843.

Rizzo, D.M. and M. Garbelotto. 2003. Sudden oak death: Endangering California and Oregon forest ecology. Frontier ecology environment. 1(5): 197-204

Rizzo, D.M., M. Garbelotto, J.M. Davidson, G.W Slaughter, and S.T. Koike. 2002. Phytophthora ramorum as the cause of extensive mortality of Quercus spp. and Lithocarpus densiflorus in California. Plant Dis. 86:205-214.

Swiecki, T.J., and E. Bernhardt. 2002. Evaluation of stem water potential and other tree and stand variables as risk factors for Phytophthora ramorum Canker development in coast live oak. In: R.D. Stanford, McCreary, K.B. Purcell (eds.). Proc. 5th Oak Symp.: Oak in California's Changing Landscape. 22-25 Oct. 2001. San Diego, Calif. USDA Forest Service, Gen. Technol. PSWGTR-184. 787-798.

United States Department of Agriculture, 2002. Animal and Plant Health Inspection Service, Phytophthora ramorum quarantine and regulation. Vol. 67, no. 31. 14 Feb. 2002. http://www. aphis.usda.gov/ppq/ispm/sod/01-054-1.pdf.

Werres, S., R. Marwitz, W.A. Man Int Veld, A.W.A.M. De Cock, P.J.M. Bonants, M. De Weerdt, K. Themann, E. Ilieva, and R.P.Baayen. 2001. Phytophthora ramorum sp. Nov., a new pathogen of Rhododendron and Viburnum. Mycol. Res. 105(10):1155-1165.

Wingfield, M.J., B. Slippers, J. Roux, and B.D. Wingfield. 2001. World wide movement of exotic forest fungi, especially in the tropics and southern hemisphere. BioScience 51:134-140.

Zentmyer G.A., J.V. Leary, L.J. Klure, and G.L. Grantham. 1976. Variability in growth of Phytophthora cinnamomi in relation to temperature. Phytopathology 66:982-986. 